\title{
The level of satisfaction among orthodontic removable appliances patients
}

\author{
Fatin Nadhirah Kamaludin Latifi*, Ida Ayu Evangelina*, Sri Susilawati** \\ *Department of Orthodontics Faculty Of Dentistry Universitas Padjadjaran \\ **Department of Dental Public Health Faculty Of Dentistry Universitas Padjadjaran
}

\section{ABSTRACT}

Introduction: Patient satisfaction is like many other psychological concepts, it is easy to understand but hard to define. The concept of satisfaction overlaps with similar themes such as happiness, contentment, and quality of life. Satisfaction is not some pre-existing phenomenon waiting to be measured, but a judgment that people form over time as they reflect on their experience. A simple and practical definition of satisfaction would be the degree to which desired goals have been achieved. Methods: The type of this research is descriptive with survey methode. Data is collected through questionnaire with the total sample of 150 respondents. The study population was based on accidental sampling, by which the sample was selected depending on who came to Orthodontic Department of RSGM FKG UNPAD, Bandung by the researcher during the period of the research. Results: The data is then analyzed using Community Satisfaction Index (Indeks Kepuasan Masyarakat) or IKM that which shows that 13 out of 14 indicators are still in B grade and overall IKM value of $7.90 \%$, which means that the level of satisfaction has yet not met the expectation among removable appliances patients in Orthodontic Department of RSGM FKG UNPAD, Bandung. Conclusion: The level of satisfaction among removable appliances patients Orthodontic are still have not met the patients' expectation.

Keywords: Satisfaction level, orthodontic removable appliances.

\section{INTRODUCTION}

Satisfaction, like many other psychological concepts, is easy to understand but hard to define. A simple and practical definition of satisfaction would be the degree to which desired goals have been achieved. ${ }^{1}$

Patient/Client satisfaction is an attitude - a person's general orientation towards a total experience of health care. Satisfaction comprises both cognitive and emotional facets and relates to previous experiences, expectations and social networks. ${ }^{1}$
Patient satisfaction is an important component of dental care. It influences patients' compliance, their use of dental services, and their anxiety, and it is also associated with health outcomes and health status. As the health care industry shifts towards a consumeroriented approach in the delivery of care, patient satisfaction surveys have become an increasingly important tool in measuring the quality of dental services. ${ }^{2}$ Patient satisfaction with dental services may be influenced by the socio-demographic characteristics of the individuals, such as age, sex, ethnicity, and socio-economic status. ${ }^{3}$ 
In orthodontics, there is emerging interest in the study of patient expectations and satisfaction. However, it is difficult to quantify them, due to the need of evaluating patients' opinions and to the long-term nature of orthodontic treatment, and the results which involve complex functional and aesthetic components. ${ }^{4}$

One possible factor related to patient compliance in orthodontics is the patient's satisfaction with the treatment process and the treatment outcome. In a previous study, it has been stated that orthodontic patients expect that the doctor-patient relationship is comfortable and warm, with a doctor who is technically competent and provides adequate information about the orthodontic problem and the procedures he or she will perform. When these expectations are not met, patients may be dissatisfied. This dissatisfaction may reduce patient compliance and eventually lead to a less than-optimal orthodontic result. An acknowledgement of the patient's perspective of orthodontic treatment is critical in ensuring the development of a comfortable doctor-patient relationship and may help improve the quality of orthodontic care. Although in many patient-centered evaluations of the effectiveness of orthodontic treatment the term "patient satisfaction" is used, this concept is in itself ambiguous. Little is known about the validity of this concept. Stated differently, the term patient satisfaction may have different underlying constructs. ${ }^{3}$

The reason why the researcher chose to study patient satisfaction among removable appliances patients in Orthodontic Department in RSGM FKG UNPAD, Bandung are because of two reasons. First, the definition of the orthodontics is all about study and treatment of malocclusions (improper bites), which may be a result of tooth irregularity, disproportionate jaw relationships and are all aesthetic-related. Therefore, patient satisfaction plays a very important role. Second, orthodontic is a long-term treatment that requires the patients to come back and forth for treatment and could take a very long time. Therefore, patient satisfaction is crucial as their opinion/ satisfaction for each visit will be different. The reason above has made me interested in studying this topic in hoping for a better improvement in the future. The aims and objectives of this study were to determine the level of satisfaction among removable appliances patients in Orthodontic Clinic of RSGM FKG UNPAD, Bandung.

\section{METHODS}

A descriptive survey was used to determine the factors influencing satisfaction among removable appliances patients in Orthodontics Department of RSGM FKG UNPAD, Bandung during the period of time from August 2011 until September 2011. A structured self-administered questionnaire was used to collect data from the patients.

The study population was based on accidental sampling, by which the sample was selected depending on who came to Orthodontic Department of RSGM FKG UNPAD, Bandung that was found by the researcher. The criteria of population are removable appliances patients aged above 12 years old, treated by the co-assistants, a minimum of 5 visits / twice activation, knows how to read and write, no cognitive disturbances, and willingly to fill the questionnaire.

The removable appliances patients who decided to exercise their right not to participate will be excluded from the sample. The number of sample that should be taken was based according to Kepmen PAN No: KEP/25/M.PAN/2/2004 which was 150.

\section{RESULTS}

In this study, the researcher studies about the management of orthodontic treatment in Orthodontic Department of RSGM FKG UNPAD, Bandung during the period of time from August to September 2011 using the descriptive data analysis that aims to provide an overview of the research based on the data and variables obtained from questionnaire. The following are the results based on data analysis.

Figure 1 showed characteristics of respondents based on age, gender, education and job. Figure 2 known of patients undergoing orthodontic treatment are at around the age of 21 years - 30 years, as many as 78 people $(52 \%)$, and the remaining 72 people $(48 \%)$ were patients aged between 12 years - 20 years. Figure 3 known that most of the removable appliances patients 


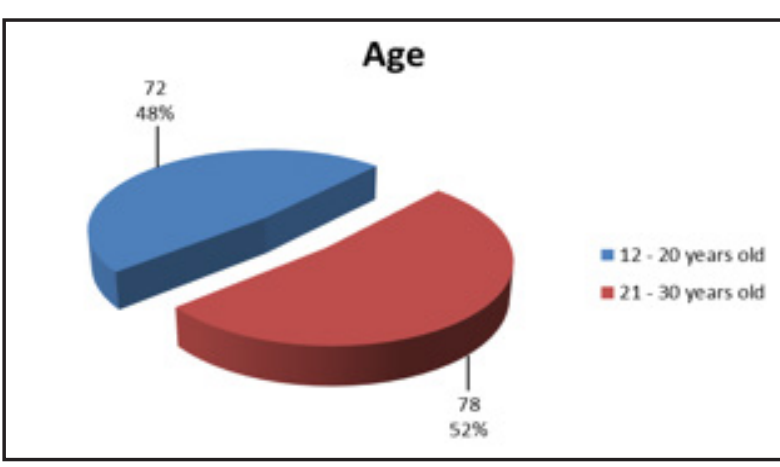

Figure 1. Characteristic distribution of respondents based on age

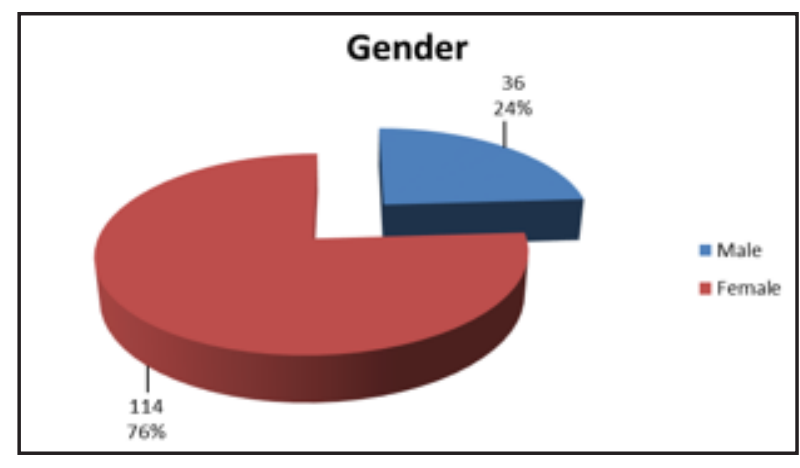

Figure 2. Characteristic distribution of respondents based on gender

undergoing orthodontic treatment are women, as many as 114 people $(76 \%)$, and the remaining 36 people $(24 \%)$ were male. From the total of 150 respondents, it is known that the majority of patients undergoing orthodontic treatment are degree-educated as many as 60 people (40\%), and the minority is master and PHD-educated by 1 person (1\%).

Figure 4 known to the majority of patients undergoing orthodontic treatment is a student and college student as many as 113 people (75\%), and the minority is the people who worked as a police and military as many as 3 people ( $2 \%$ ).

According to table 1 , it is known that the majority of the respondents answered quite easy, with the total of 65 respondents, meanwhile the least answered not easy at all, with the total of 5 respondents. Community Satisfaction Index (Indeks Kepuasan Masyarakat) is $69.60 \%$.

According to table 1 , it is known that the majority of the respondents answered quite easy, with the total of 70 respondents, meanwhile the least answered not easy, with the total of 6 respondents and none answered not easy at all.

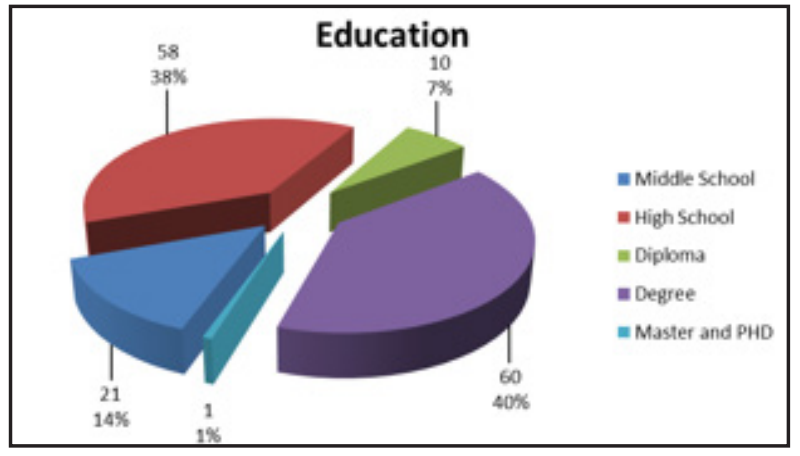

Figure 3. Characteristic distribution of respondents based on education

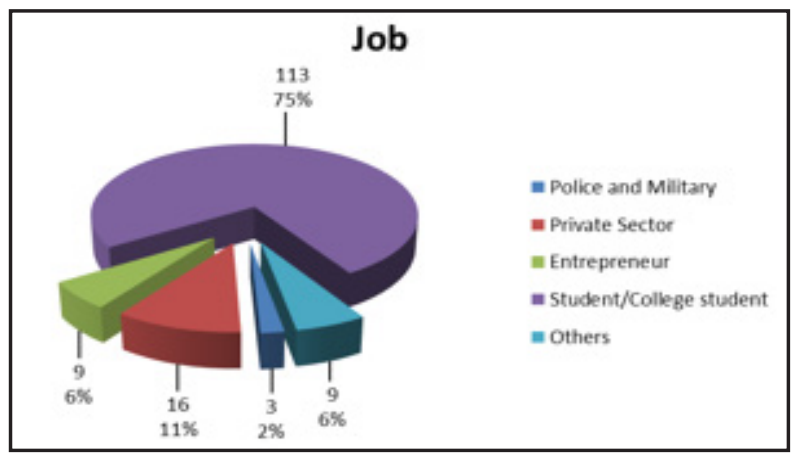

Figure 4. Characteristic distribution of respondents based on job

Table 1. Removable appliances patients' responses for service procedures indicator and responses for terms of services indicator

\begin{tabular}{|c|c|c|c|c|}
\hline & Criteria of the Score & Freq. & Value $(\mathrm{S} \times \mathrm{F})$ & IKM \\
\hline \multicolumn{5}{|c|}{ Responses for Service Procedures Indicator } \\
\hline 1 & Not Easy At All & 5 & 5 & $69,60 \%$ \\
\hline 2 & Not Easy & 6 & 12 & \\
\hline 3 & Quite Easy & 65 & 195 & \\
\hline 4 & Easy & 60 & 240 & \\
\hline \multirow[t]{2}{*}{5} & Very Easy & 14 & 70 & \\
\hline & Total & 150 & 522 & \\
\hline \multicolumn{5}{|c|}{ Responses for Terms of Services Indicator } \\
\hline 1 & Not Easy At All & 0 & 0 & $71.07 \%$ \\
\hline 2 & Not Easy & 6 & 12 & \\
\hline 3 & Quite Easy & 70 & 210 & \\
\hline 4 & Easy & 59 & 236 & \\
\hline \multirow[t]{2}{*}{5} & Very Easy & 15 & 75 & \\
\hline & Total & 150 & 533 & \\
\hline
\end{tabular}

Community Satisfaction Index (Indeks Kepuasan Masyarakat) is $71.07 \%$. According to table 2 , it is known that the majority of the respondents answered clear, with the total of 64 respondents, 
meanwhile the least answered not clear at all, with the total of 1 respondent. Community Satisfaction Index (Indeks Kepuasan Masyarakat) is 74.53\%.

According to table 2, it is known that the majority of the respondents answered discipline, with the total of 76 respondents, meanwhile the least answered not discipline, with the total of 5 respondents and none answered not discipline at all. Community Satisfaction Index (Indeks Kepuasan Masyarakat) is $76.40 \%$. According table 3 , it is known that the majority of the respondents answered responsible, with the total of 103 respondents, meanwhile the least answered not responsible at all, with the total of 1 respondent and none answered not responsible. Community Satisfaction Index (Indeks Kepuasan Masyarakat) is $76.67 \%$.

According table 3, it is known that the majority of the respondents answered capable, with the total of 100 respondents, meanwhile the least answered not capable, with the total of 1 respondent and none answered not capable at all. Community Satisfaction Index (Indeks Kepuasan Masyarakat) is $79.60 \%$.

According to the above table 4, it is known that the majority of the respondents answered quite fast, with the total of 85 respondents, meanwhile the least answered not fast at all, with the total of 2 respondents. Community Satisfaction Index (Indeks Kepuasan Masyarakat) is 63.73\%.

Table 2. Removable appliances patients' responses for clarification of the co-assistants and responses for discipline of the co-assistants

\begin{tabular}{ccccc}
\hline & Criteria of the Score & Freq. & Value $(\mathrm{S} \times \mathrm{F})$ & IKM \\
\hline \multicolumn{5}{c}{ Responses for Clarification of the Co-assistants } \\
1 & Not Easy At All & 1 & 1 & $74,53 \%$ \\
2 & Not Easy & 9 & 18 & 144 \\
3 & Quite Easy & 48 & 256 \\
4 & Easy & 64 & 140 \\
5 & Very Easy & 28 & 559 \\
& Total & 150 & 0 \\
& Responses for Discipline of the Co-assistants \\
\hline 1 & Not Discipline At All & 0 & 10 \\
2 & Not Discipline & 5 & 129 \\
3 & Quite Discipline & 43 & 304 \\
4 & Discipline & 76 & 130 \\
\hline 5 & Very Discipline & 26 & 573 \\
\hline
\end{tabular}

According table 4, it is known that the majority of the respondents answered quite fair, with the total of 77 respondents, meanwhile the least answered not fair, with the total of 3 respondents and none answered not fair at all. Community Satisfaction Index (Indeks Kepuasan Masyarakat) is $70.93 \%$.

Accordingtable5, it isknownthat themajority of the respondents answered good, with the total of 71 respondents, meanwhile the least answered not good, the total of 1 respondent and none

Table 3. Removable appliances patients' responses for responsibility of the co-assistants and responses for capability of the co-assistants

\begin{tabular}{|c|c|c|c|c|}
\hline & Criteria of the Score & Freq. & Value $(\mathrm{S} \times \mathrm{F})$ & IKM \\
\hline \multicolumn{5}{|c|}{ Responses for Responsibility of the Co-assistants } \\
\hline 1 & Not Discipline At All & 1 & 1 & $76,67 \%$ \\
\hline 2 & Not Discipline & 0 & 0 & \\
\hline 3 & Quite Discipline & 34 & 102 & \\
\hline 4 & Discipline & 103 & 412 & \\
\hline \multirow[t]{2}{*}{5} & Very Discipline & 12 & 60 & \\
\hline & Total & 150 & 575 & \\
\hline \multicolumn{5}{|c|}{ Responses for Capability of the Co-assistants } \\
\hline 1 & Not Capable At All & 0 & 0 & $79,60 \%$ \\
\hline 2 & Not Capable & 1 & 2 & \\
\hline 3 & Quite Capable & 25 & 75 & \\
\hline 4 & Capable & 100 & 400 & \\
\hline \multirow[t]{2}{*}{5} & Very Capable & 24 & 120 & \\
\hline & Total & 150 & 597 & \\
\hline
\end{tabular}

Table 4. Removable appliances patients' responses for speed of services and responses for justice in receiving service

\begin{tabular}{ccccc}
\hline & Criteria of the Score & Freq. & Value $(\mathrm{S} \times \mathrm{F})$ & IKM \\
\hline 1 & Responses for Speed of Services & \\
\hline 2 & Not Fast At All & 2 & 2 & $63,73 \%$ \\
3 & Not Fast & 18 & 36 & \\
4 & Quite Fast & 85 & 255 \\
5 & Fast & 40 & 160 \\
& Very Fast & 5 & 25 \\
\hline & Total & 150 & 478 \\
\hline 1 & Responses for Justice in Receiving Service \\
\hline 2 & Not Fair At All & 0 & 0 \\
3 & Not Fair & 3 & 6 \\
4 & Quite Fair & 77 & 231 \\
5 & Fair & 55 & 220 \\
\hline & Very Fair & 15 & 75 \\
\hline
\end{tabular}


answered not good at all. Community Satisfaction Index (Indeks Kepuasan Masyarakat) is $86.13 \%$.

According table 5, it is known that the majority of the respondents answered reasonable, with the total of 78 respondents, meanwhile the least answered not reasonable, with the total of 4 respondents and none answered not reasonable at all. Community Satisfaction Index (Indeks Kepuasan Masyarakat) is $77.60 \%$.

According table 6 , it is known that the majority of the respondents answered appropriate, with the total of 75 respondents, meanwhile the least answered not appropriate, with the total of 4 respondents and none answered not appropriate at all. Community Satisfaction Index (Indeks Kepuasan Masyarakat) is $74.53 \%$.

According table 6 , it is known that the majority of the respondents answered certain, with the total of 66 respondents, meanwhile the least answered not certain at all, with the total of 1 respondent. Community Satisfaction Index (Indeks Kepuasan Masyarakat) is $71.07 \%$.

According table 7 , it is known that the majority of the respondents answered quite clean, with the total of 56 respondents, meanwhile the least answered not clean at all, with the total of 4 respondents. Community Satisfaction Index (Indeks Kepuasan Masyarakat) is $69.33 \%$.

Table 5. Removable appliances patients' responses for politeness, courtesy and attention of the co-assistants and responses for reasonableness of the service charges

\begin{tabular}{|c|c|c|c|c|}
\hline & Criteria of the Score & Freq. & $\begin{array}{l}\text { Value } \\
(\mathrm{S} \times \mathrm{F})\end{array}$ & IKM \\
\hline \multicolumn{5}{|c|}{ Responses for Politeness, courtesy and attention of the } \\
\hline \multicolumn{5}{|c|}{ Co-assistants } \\
\hline 1 & Not Good At All & 0 & 0 & $86,13 \%$ \\
\hline 2 & Not Good & 1 & 2 & \\
\hline 3 & Quite Good & 15 & 45 & \\
\hline 4 & Good & 71 & 284 & \\
\hline \multirow[t]{2}{*}{5} & Very Good & 63 & 315 & \\
\hline & Total & 150 & 646 & \\
\hline \multicolumn{5}{|c|}{ Responses for Reasonableness of the Service Charges } \\
\hline 1 & Not Reasonable At All & 0 & 0 & $77,60 \%$ \\
\hline 2 & Not Reasonable & 4 & 8 & \\
\hline 3 & Quite Reasonable & 39 & 117 & \\
\hline 4 & Reasonable & 78 & 312 & \\
\hline \multirow[t]{2}{*}{5} & Very Reasonable & 29 & 145 & \\
\hline & Total & 150 & 582 & \\
\hline
\end{tabular}

According table 8, it is known that the majority of the respondents answered safe, with the total of 71 respondents, meanwhile the least answered not safe at all, with the total of 1 respondent. Community Satisfaction Index (Indeks Kepuasan Masyarakat) is $73.33 \%$.

According table 9 the interval categories of respondents based on overall scoring for each question and are already mentioned in Chapter III.

Table 6. Removable appliances patients' responses for compliance costs with local government and responses for certainty of service schedule

\begin{tabular}{|c|c|c|c|c|}
\hline & Criteria of the Score & Freq. & Value $(\mathrm{S} \times \mathrm{F})$ & IKM \\
\hline \multicolumn{5}{|c|}{ Responses for Compliance Costs with Local Government } \\
\hline 1 & $\begin{array}{c}\text { Not Appropriate } \\
\text { At All }\end{array}$ & 0 & 0 & $74,53 \%$ \\
\hline 2 & Not Appropriate & 4 & 8 & \\
\hline 3 & Quite Appropriate & 52 & 156 & \\
\hline 4 & Appropriate & 75 & 300 & \\
\hline \multirow[t]{2}{*}{5} & Very Appropriate & 19 & 95 & \\
\hline & Total & 150 & 559 & \\
\hline \multicolumn{5}{|c|}{ Responses for Certainty of Service Schedule } \\
\hline 1 & Not Certain At All & 1 & 1 & $71,07 \%$ \\
\hline 2 & Not Certain & 7 & 14 & \\
\hline 3 & Quite Certain & 63 & 189 & \\
\hline 4 & Certain & 66 & 264 & \\
\hline \multirow[t]{2}{*}{5} & Very Certain & 13 & 65 & \\
\hline & Total & 150 & 533 & \\
\hline
\end{tabular}

Table 7. Removable appliances patients' responses for environmental cleanliness and responses for environmental safety

\begin{tabular}{|c|c|c|c|c|}
\hline & Criteria of the Score & Freq. & Value $(\mathrm{S} \times \mathrm{F})$ & IKM \\
\hline \multicolumn{5}{|c|}{ Responses for Environmental Cleanliness } \\
\hline 1 & Not Clean At All & 4 & 4 & $69,33 \%$ \\
\hline 2 & Not Clean & 19 & 38 & \\
\hline 3 & Quite Clean & 56 & 168 & \\
\hline 4 & Clean & 45 & 180 & \\
\hline \multirow[t]{2}{*}{5} & Very Clean & 26 & 130 & \\
\hline & Total & 150 & 520 & \\
\hline \multicolumn{5}{|c|}{ Responses for Environmental Safety } \\
\hline 1 & Not Safe At All & 1 & 1 & $73,33 \%$ \\
\hline 2 & Not Safe & 9 & 18 & \\
\hline 3 & Quite Safe & 49 & 147 & \\
\hline 4 & Safe & 71 & 284 & \\
\hline \multirow[t]{2}{*}{5} & Very Safe & 20 & 100 & \\
\hline & Total & 150 & 550 & \\
\hline
\end{tabular}


Table 8. Interval categories of respondents

\begin{tabular}{ccccc}
\hline No. & $\begin{array}{c}\text { Interval } \\
\text { Value }\end{array}$ & $\begin{array}{c}\text { IKM Con- } \\
\text { version }\end{array}$ & $\begin{array}{c}\text { Quality of } \\
\text { service }\end{array}$ & $\begin{array}{c}\text { Performanc- } \\
\text { es }\end{array}$ \\
\hline 1 & $1,00-1,75$ & $25-43.75$ & D & Poor \\
2 & $1,75-2.50$ & $\begin{array}{c}43.76- \\
62.50\end{array}$ & C & Not good \\
& & & \\
3 & $2,50-3.25$ & $62.51-$ & B & Good \\
& & $\wedge \wedge 1.25$ & & \\
4 & $3,25-4,00$ & 81.26 & A & Very good \\
& & -100.00 & & \\
\hline
\end{tabular}

Table 9. Categories of the respondents based on ikm value

\begin{tabular}{|c|c|c|c|}
\hline No. & Interval Value & IKM & Performances \\
\hline 1 & Service Procedures & $69,60 \%$ & Good \\
\hline 2 & Terms of Services & & $71,07 \%$ \\
\hline 3 & $\begin{array}{l}\text { Clarification of the Co-as- } \\
\text { sistants }\end{array}$ & $74,53 \%$ & Good \\
\hline 4 & $\begin{array}{l}\text { Discipline of the Co-assis- } \\
\text { tants }\end{array}$ & $76,40 \%$ & Good \\
\hline 5 & $\begin{array}{l}\text { Responsibility of the Co-as- } \\
\text { sistants }\end{array}$ & $76,67 \%$ & Good \\
\hline 6 & $\begin{array}{l}\text { Capability of the Co-assis- } \\
\text { tants }\end{array}$ & $79,60 \%$ & Good \\
\hline 7 & Speed of Services & $63,73 \%$ & Good \\
\hline 8 & Justice in Receiving Service & $70,93 \%$ & Good \\
\hline 9 & $\begin{array}{l}\text { Politeness, Courtesy and } \\
\text { Attention of the Co-assis- } \\
\text { tants }\end{array}$ & $86,13 \%$ & Very Good \\
\hline 10 & $\begin{array}{l}\text { Reasonableness of the Ser- } \\
\text { vice Charges }\end{array}$ & $77,60 \%$ & Good \\
\hline 11 & $\begin{array}{l}\text { Compliance costs with Lo- } \\
\text { cal Government }\end{array}$ & $74,53 \%$ & Good \\
\hline 12 & $\begin{array}{l}\text { Certainty -of } \quad \text { Service } \\
\text { Schedule }\end{array}$ & $71,07 \%$ & Good \\
\hline 13 & Environmental Cleanliness & $69,33 \%$ & Good \\
\hline 14 & Environmental Safety & $73,33 \%$ & Good \\
\hline & IKM Aggregate & $73,90 \%$ & Good \\
\hline
\end{tabular}

According tabel 10, the gold standard (BENCHMARK) for IKM is $80 \%$, in consideration that in figure 1 is categorized as very good in IKM value.According to the table and diagram above, it can be concluded that the overall Community Satisfaction Index (Indeks Kepuasan Masyarakat)is $73.90 \%$, where the highest satisfaction is achieved by the Politeness, Courtesy, and Attention given Co-assistants indicator with the IKM value of $86.13 \%$ and the lowest satisfaction is the Speed of Services indicator with the IKM value of $63.73 \%$.

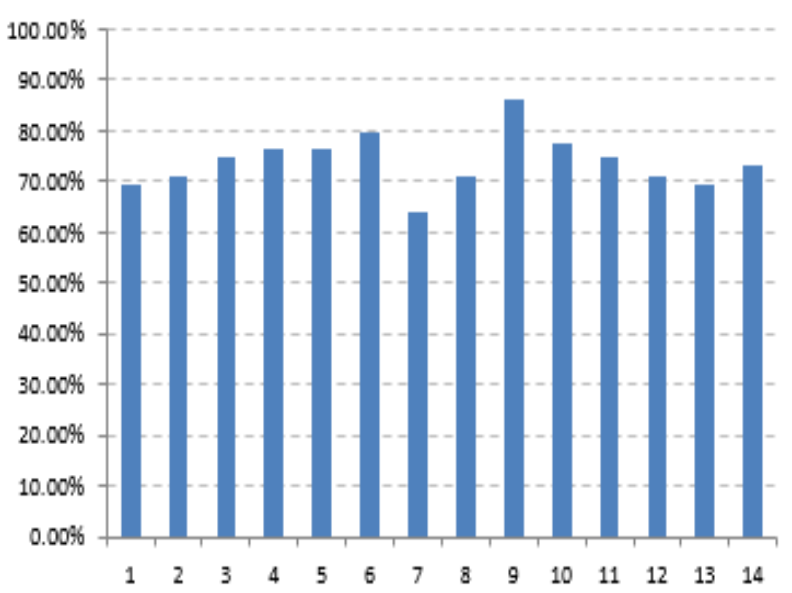

Figure 1. Categories of the respondents based on ikm value

\section{DISCUSSION}

According table 16 and Figure 1, the overall aggregate of IKM achieved is $73.90 \%$. It can be well concluded here that the quality of services offered by the co-assistants to removable appliances patients in Orthodontic Department of RSGM FKG UNPAD are in Good criteria. The 13 indicators that are in Good criteria are Service Procedures (69.60\%); Terms of Services (71.07\%); Clarification of the Co-assistants (74.53\%); Disciplines of the Co-assistants (76.40\%); Responsibility of the Coassistants (76.67\%); Capability of the Co-assistants (79.60\%); Speed of Services (63.73\%); Justice in Receiving Service (70.93\%); Reasonableness of the Service Charges (77.60\%); Compliance Cost with the Local Government (74.53\%); Certainty of Service Schedule (71.07\%); Environmental Cleanliness (69.33\%); and last but not least Environmental Safety (73.33\%). Only 1 indicator achieved the GOLD STANDARD BENCHMARK of IKM value, the Very Good criteria which is the Politeness, Courtesy, and Attention given by the Co-assistant indicator, with the percentage of $86.13 \%$.

Service Procedure indicator, the IKM value is in Good criteria. Most of the removable appliances patients find the stages of services are not easy and not straightforward. They have to go through quite a lot of stages of procedures and have to come back and forth to the hospital. Some also complained that the co-assistants took quite a long time before the insertion of the appliances stage. This leads to dissatisfaction. 
Terms of Services indicator, the IKM value is in Good criteria. Most of the patients complained they have not been informed earlier about the terms and conditions of becoming a removable appliances patient. They were not informed that not all patients are eligible as the co-assistants have to consult with the residents or specialists first before accepting them as patients. This can lead to dissatisfaction.

Clarification of the Co-assistants indicator, the IKM value is in Good criteria. The patients have not been well-explained about the procedure of the treatment before the treatment was done. Patients usually have a lot of questions to ask before the treatment, the questions were basically about the treatment planning, the expected results from the treatment, the costs that they are going to pay and how long is the treatment being done. Co-assistants sometimes failed to give a certain answers to the questions are not able to explained the procedure of the treatment and this makes the patients confused which will lead to dissatisfaction.

Discipline of the Co-assistants indicator, the IKM value is in Good criteria. The co-assistants are lack of discipline during giving treatments to the patients. Based on the observation by the researcher, some of the co-assistants are not tidy in appearance. For example, for the girls they do not tie their hair during giving treatment to the patients, some of them do not wear gloves and masks while giving treatment to the patients, some of them unbutton their lab coat during giving treatment, and some wear improper clothes. These examples show lack of discipline among the co-assistants that leads to patient dissatisfaction.

Responsibility of the Co-assistants indicator, the IKM value is in Good criteria. The patients feel that the co-assistant was not responsible enough in handling them during treatment. They also feel that if there are any consequences happen, the coassistants are not tough enough to be responsible towards the consequences and this can lead to dissatisfaction.

Capability of the Co-assistants indicator, the IKM value is in Good criteria. Based on the judgement of the patients, the co-assistants are lack of experience as they are still new and not as experienced as the residents and specialists.
The patients fear that the co-assistants might mess with their teeth. When the patients are not confident with the persons who treat them, this will leads to dissatisfaction.

Speed of Services indicator, the IKM value is in Good criteria. The co-assistants take quite a long time to treat the patients. The time given to treat each patient are always not enough and they have to take more time and thus causing the delay to the next patient. The co-assistants have to wait for the residents or specialist in charge to supervise their treatment and this has cause the patient to wait longer and sometimes they become grumpy for having to wait for too long. This can lead to dissatisfaction.

Justice in Receiving Service indicator, the IKM value is in Good criteria. The patients feel like the co-assistants are injustice in order giving treatment to their patients. Some of the co-assistants treat their favourite patients first without considering who comes first or treating 2 patients at a same time that took more time than if treating 1 patient. This can lead to dissatisfaction.

Politeness, Courtesy and Attention given by Co-assistants indicator, is the only indicator that is in Very Good criteria in this study. It is proven that the co-assistants in Orthodontic Department in RSGM FKG UNPAD are polite, courtesy and always pays attention to their patients' needs and complaints. They tend to have a very good relationship with the patients and patients who communicate more with their co-assistants shows more satisfaction than those who less communicate. Happy patients lead to satisfaction.

Reasonableness of the Service Charges indicator, the IKM value is in Good criteria. The patients think that they are being overcharged. Patients feel like what they pay were not compatible with the treatment that they receive. Orthodontic treatment using removable appliances usually take a very long time and by having to pay for each visit is like a burden to the patients especially to the lower and middle class. This can lead to dissatisfaction.

Compliance Cost with the Local Government indicator, the IKM value is in Good criteria. The patients think that the cost charged at Orthodontic Department of RSGM FKG UNPAD do not comply with the cost determine by the local government. They feel like the other hospital or clinic offers 
the same treatment but with lower cost. This can lead to dissatisfaction.

Certainty of Service Schedule indicator, the IKM value is in Good criteria. The co-assistants are not sticking up with their schedule. Some of them come late for the appointment and made the patients wait for quite a long time in the waiting room and automatically causing the delay to the next patients. Patients become unhappy for having to wait too long in the waiting room and unhappy patients lead to dissatisfaction.

Environmental Cleanliness indicator, the IKM value is in Good criteria. The environment at the waiting and treatment room are not clean enough. Based on the observation from the researcher, there a lot of rubbish thrown everywhere in the waiting room simply because there are no dustbin provided by the Orthodontic Department in the waiting room. Meanwhile in the treatment room, some of the co-assistants do not clean the dental chair and the surroundings of the dental chair as it was already used before. It is not hygienic and can lead to patient dissatisfaction. Environmental Safety indicator, the IKM value is in Good criteria. The patients do not feel safe whenever they are at the Orthodontic Department of RSGM FKG UNPAD. They always feel like they have to take care of their belongings all the time as there are no guard or locker for them to put their belongings while receiving treatment from the co-assistants.

\section{CONCLUSION}

The level of satisfaction among removable appliances patients Orthodontic are in good criteria.

\section{REFERENCES}

1. Health Boards Executive (HeBE). Measurement of patient satisfaction guidelines: health strategy implementation project 2003/ The Health Boards Executive. 2003. p. 10-12.

2. Sur H, Hayran O; Yildirim C; Mumcu G. Patient satisfaction in dental outpatient clinics in Turkey. Croat Med J. 2004 Oct;45(5):651-4.

3. Bos A, Vosselman N, Hoogstraten J, PrahlAndersen B. Patient compliance: Adeterminant of patient satisfaction? Angle Orthod. 2005 Jul;75(4):526-31.

4. Baleski C, Moresca RC, Eros N. Evaluation of level of patient satisfaction in orthodontic patients considering professional performance. Dent Press J Orthod 2010;15(6):56.e1-12. 